\title{
Celebrating the work of Nobel Laureate Paul Modrich
}

\author{
Guo-Min Li \\ Department of Biochemistry and Molecular Biology, Norris Comprehensive Cancer Center, University of Southern California Keck School of \\ Medicine, University of Southern California, Los Angeles, CA 90033, USA
}

Received December 8, 2015; accepted December 12, 2015; published online December 17, 2015

Citation: $\quad$ Li, G.M. (2016). Celebrating the work of Nobel Laureate Paul Modrich. Sci China Life Sci 59, 93-96. doi: 10.1007/s11427-015-4989-y

On October 7, 2015, the Nobel Prize Committee announced that the 2015 Nobel Prize in Chemistry had been awarded jointly to Professors Paul Modrich, Tomas Lindahl and Aziz Sancar (Figure 1), each of whom made ground-breaking discoveries about the molecular mechanisms of DNA Repair. In one of life's unpredictable turns, Paul was among the last individuals in his entire personal, professional and social network to learn of the Committee's decision, because Paul was very far "off-the-grid" at the time of the announcement. The news that he had been selected as a 2015 Nobel Laureate may have taken Paul by surprise, but it certainly was not a surprise to most, if not all, of Paul's colleagues, students, family and friends.

As a scientist and person, Paul exemplifies excellence, dedication and the highest level of commitment to science and the scientific process, to the extent that he stands head and shoulders apart and above the rest of us. Paul is also modest, approachable, honest, unpretentious and an excellent mentor to the young scientists in his laboratory. I had the honor of working for Paul from 1991 to 1995, one of the most exciting times in the field of DNA repair, and certainly, at least so far, the highlight of my personal and professional life.

Paul was born and grew up in Raton, New Mexico. His interest in DNA and nucleic acids was inspired by his father, the local high school biology teacher, who encouraged him to learn about the DNA when Paul was a high school student. His father's advice had influenced Paul to obtain his BS degree in biology at Massachusetts Institute of

email: guominli@usc.edu

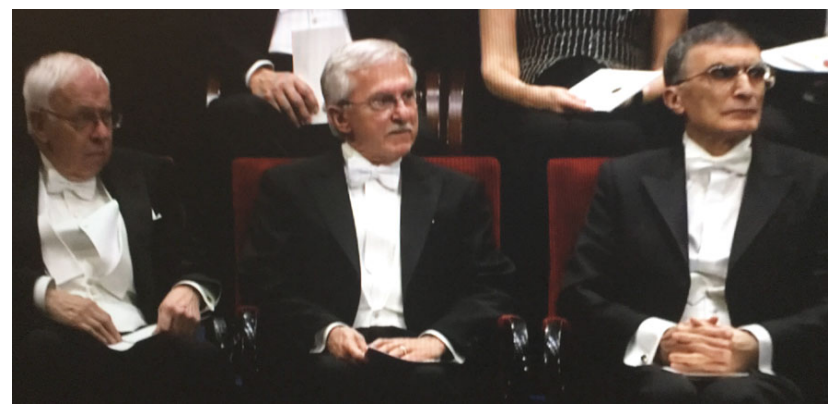

Figure 1 (color online) Paul Modrich, Aziz Sancar and Tomas Lindahl share the 2015 Nobel Prize in Chemistry. The photo was taken at the Nobel Award Ceremony on December 10, 2015, when professors Lindahl (left), Modrich (middle) and Sancar (right) received their awards from the King of Sweden, Carl XVI Gustaf, in the Concert Hall, Stockholm, Sweden.

Technology. As a doctoral student, Paul studied nucleic acid metabolism and the enzymes that carry out DNA transactions in Dr. I. Robert Lehman's laboratory at Stanford University. Paul characterized DNA ligase from Escherichia coli (Modrich et al., 1973; Modrich and Lehman, 1970, 1971; Modrich et al., 1972), an enzyme that performs an essential step, and often the critical last step, in multiple pathways of DNA replication and repair. After postdoctoral training with Charles Richardson at Harvard University, studying bacteriophage T7 DNA polymerases (Modrich and Richardson, 1975a, b), Paul took a faculty position at the University of California, Berkeley in 1974. He then joined Duke University's faculty in 1976, where he currently holds the position of James B. Duke Professor of Biochemistry and an investigator at the Howard Hughes Medical Institute. 
Paul's early studies concentrated on the E. coli experimental model system, arguably the most important experimental model system for analyzing and understanding the molecular mechanisms of DNA replication and repair. His seminal work on the molecular mechanism of DNA mismatch repair (MMR) in E. coli laid the groundwork for later breakthroughs in understanding the biochemical basis of human colon carcinogenesis and for understanding cellular resistance to some classes of chemotherapeutic drugs for treating human cancer.

In his early $E$. coli studies, Paul provided an unequivocal mechanistic basis for the strand-specificity (and accuracy) of MMR, which had remained an unsolved question and a major roadblock to progress in the field. Based on earlier observations that nascent $E$. coli DNA is transiently under-methylated at duplex d(GATC) sites (Marinus, 1976), and a hypothesis first advanced by Matthew Meselson (Wagner and Meselson, 1976), Paul, Meselson and their colleagues provided definitive evidence that the asymmetry of hemi-methylated nascent DNA confers strand-specificity on E. coli MMR (Pukkila et al., 1983). It is important to realize that in the absence of strand-specificity, the MMR system would be entirely useless, because the accuracy of a non-strand-specific MMR reaction cannot exceed 0.5 (i.e., $50 \%$ chance of correct repair).

In the early 1980s, Paul developed a powerful in vitro assay for strand-specific methyl-directed MMR ( $\mathrm{Lu}$ et al., 1983). Using this assay, Paul's lab identified, purified and characterized E. coli MutS (Su and Modrich, 1986), MutL (Grilley et al., 1989) and MutH (Welsh et al., 1987), the three E. coli proteins whose dedicated primary role is in MMR. As the milestone achievement in the late 1980s, Paul's laboratory reconstituted E. coli MMR in vitro using purified components (Lahue et al., 1989). This groundbreaking work led to Paul's later studies elucidating the mechanism of E. coli methyl-directed MMR (Allen et al., 1997; Au et al., 1992; Cooper et al., 1993; Dao and Modrich, 1998; Grilley et al., 1993; Grilley et al., 1990; Grilley et al., 1989; Worth et al., 1994; Yamaguchi et al., 1998).

In the 1990s, Paul and his colleagues extended these studies to eukaryotic cells, demonstrating that human and Drosophila cells express enzymes that carry out strand-specific MMR, in a reaction that resembles, but is significantly different from E. coli MMR (Holmes et al., 1990). In 1993, Bert Vogelstein (Aaltonen et al., 1993), Stephen Thibodeau (Thibodeau et al., 1993) and Manuel Perucho (Ionov et al., 1993) independently reported that instability of microsatellite sequences is associated with hereditary non-polypopsis colorectal cancer (HNPCC, also called Lynch Syndrome) and a subset of sporadic colorectal cancers. This correlation, and the fact that simple repetitive sequences are also highly unstable in MMR-deficient $E$. coli
(Levinson and Gutman, 1987a, b), led to the next milestone discovery out of Paul's laboratory: namely, that cancer cells displaying microsatellite instability are defective in MMR (Parsons et al., 1993). This discovery is consistent with genetic studies from the laboratories of Richard Kolodner, Bert Vogelstein and Mike Liskay, which showed that mutations in $h M S H 2, h M L H 1$ and $h P M S 2$ genes, the human homologs of $m u t S$ and $m u t L$, are causally linked to HNPCC (Bronner et al., 1994; Fishel et al., 1993; Kolodner et al., 1994; Leach et al., 1993; Nicolaides et al., 1994; Papadopoulos et al., 1994).

Collectively, these discoveries elevated the whole field of DNA repair, previously thought of as a collection of "housekeeping" pathways, to a new level of significance. DNA repair, largely as a result of the work of Paul Modrich, Richard Kolodner and Bert Vogelstein, but also complemented by the work of Aziz Sancar, Phil Hanawalt, Richard Wood and others, was named Science magazine's Molecule of the Year in December, 1994 (Koshland, 1994).

Paul's laboratory went on to purify and characterize key human MMR proteins hMutL $\alpha$ (Li and Modrich, 1995), hMutS $\alpha$ (Drummond et al., 1995), DNA polymerase $\delta$ (Longley et al., 1997), hMutS $\beta$ (Genschel et al., 1998) and exonuclease I (Genschel et al., 2002), taking advantage of both MMR-deficient cancer cell lines and biochemical "mutants" generated by fractionation, which ultimately allowed Paul's lab to reconstitute and elucidate the mechanism of human MMR (Constantin et al., 2005; Dzantiev et al., 2004; Kadyrov et al., 2006).

In summary, Paul's laboratory, working over three decades, was always at the forefront of the field, being the first to answer the unanswered questions about MMR and its impact on human health. Therefore, Paul, Aziz Sancar, and Tomas Lindahl are three scientists who are highly deserving of the 2015 Nobel Prize in Chemistry. All who know Paul are extremely grateful to him for his invaluable contribution to this field of research.

Compliance and ethics The author(s) declare that they have no conflict of interest.

Acknowledgements The author's laboratory is currently supported by NIH grants (R01CA167181, R01GM089684 and R21CA192003), and the University of Southern California Norris Comprehensive Cancer Center.

Aaltonen, L.A., Peltomäki, P., Leach, F.S., Sistonen, P., Pylkkänen, L., Mecklin, J.-P., Järvinen, H., Powell, S.M., Jen, J., Hamilton, S.R., Petersen, G.M., Kinzler, K.W.,Vogelstein, B., and Delachapelle, A. (1993). Clues to the pathogenesis of familial colorectal cancer. Science 260, 812-816.

Allen, D.J., Makhov, A., Grilley, M., Taylor, J., Thresher, R., Modrich, P., and Griffith, J.D. (1997). MutS mediates heteroduplex loop formation by a translocation mechanism. EMBO J 16, 4467-4476.

Au, K.G., Welsh, K., and Modrich, P. (1992). Initiation of methyl-directed 
mismatch repair. J Biol Chem 267, 12142-12148.

Bronner, C.E., Baker, S.M., Morrison, P.T., Warren, G., Smith, L.G., Lescoe, M.K., Kane, M., Earabino, C., Lipford, J., Lindblom, A., Tanergard, P., Bollag, R.J., Godwin, A.R., Ward, D.C., Nordenskjold M., Fishel, R., Kolodner, R., and Liskay, R.M. (1994). Mutation in the DNA mismatch repair gene homologue hMLH1 is associated with hereditary non-polyposis colon cancer. Nature 368, 258-261.

Constantin, N., Dzantiev, L., Kadyrov, F.A., and Modrich, P. (2005). Human mismatch repair: Reconstitution of a nick-directed bidirectional reaction. J Biol Chem 280, 39752-39761.

Cooper, D.L., Lahue, R.S., and Modrich, P. (1993). Methyl-directed mismatch repair is bidirectional. J Biol Chem 268, 11823-11829.

Dao, V., and Modrich, P. (1998). Mismatch-, MutS-, MutL-, and helicase II-dependent unwinding from the single-strand break of an incised heteroduplex. J Biol Chem 273, 9202-9207.

Drummond, J.T., Li, G.M., Longley, M.J., and Modrich, P. (1995). Isolation of an hMSH2-p160 heterodimer that restores DNA mismatch repair to tumor cells. Science 268, 1909-1912.

Dzantiev, L., Constantin, N., Genschel, J., Iyer, R.R., Burgers, P.M., and Modrich, P. (2004). A defined human system that supports bidirectional mismatch-provoked excision. Mol cell 15, 31-41.

Fishel, R., Lescoe, M.K., Rao, M.R., Copeland, N.G., Jenkins, N.A., Garber, J., Kane, M., and Kolodner, R. (1993). The human mutator gene homolog $\mathrm{MSH} 2$ and its association with hereditary nonpolyposis colon cancer. Cell 75, 1027-1038.

Genschel, J., Bazemore, L.R., and Modrich, P. (2002). Human exonuclease $\mathrm{I}$ is required for 5' and 3' mismatch repair. J Biol Chem 277, 13302-13311.

Genschel, J., Littman, S.J., Drummond, J.T., and Modrich, P. (1998). Isolation of MutSbeta from human cells and comparison of the mismatch repair specificities of MutSbeta and MutSalpha. J Biol Chem 273, 19895-19901.

Grilley, M., Griffith, J., and Modrich, P. (1993). Bidirectional excision in methyl-directed mismatch repair. J Biol Chem 268, 11830-11837.

Grilley, M., Holmes, J., Yashar, B., and Modrich, P. (1990). Mechanisms of DNA-mismatch correction. Mutat Res 236, 253-267.

Grilley, M., Welsh, K.M., Su, S.S., and Modrich, P. (1989). Isolation and characterization of the Escherichia coli mutL gene product. J Biol Chem 264, 1000-1004.

Holmes, J., Jr., Clark, S., and Modrich, P. (1990). Strand-specific mismatch correction in nuclear extracts of human and Drosophila melanogaster cell lines. Proc Natl Acad Sci USA 87, 5837-5841.

Ionov, Y., Peinado, M.A., Malkhosyan, S., Shibata, D., and Perucho, M. (1993). Ubiquitous somatic mutations in simple repeated sequences reveal a new mechanism for colonic carcinogenesis. Nature 363, 558-561.

Kadyrov, F.A., Dzantiev, L., Constantin, N., and Modrich, P. (2006). Endonucleolytic function of MutLalpha in human mismatch repair. Cell 126, 297-308.

Kolodner, R.D., Hall, N.R., Lipford, J., Kane, M.F., Rao, M.R., Morrison, P., Wirth, L., Finan, P.J., Burn, J., Chapman, P., Earabino C., Merchant, E., and Bishop, D.T. (1994). Structure of the human MSH2 locus and analysis of two Muir-Torre kindreds for msh2 mutations. Genomics 24, 516-526.

Koshland, D.E., Jr. (1994). Molecule of the year: the DNA repair enzyme. Science 266, 1925.

Lahue, R.S., Au, K.G., and Modrich, P. (1989). DNA mismatch correction in a defined system. Science 245, 160-164.

Leach, F.S., Nicolaides, N.C., Papadopoulos, N., Liu, B., Jen, J., Parsons, R., Peltomaki, P., Sistonen, P., Aaltonen, L.A., Nystrom, L.M., Guan, X.Y., Zhang, J., Meltzer, P.S., Yu, J.W., Kao, F.T, Chen, D.J., Cerosaletti, K.M., Fournier, R.E.K., Todd, S., Lewis, T., Leach, R.J., Naylor, S.L., Weissenbach, J., Mecklin, J.P., Jarvinen, H., Petersen, G.M., Hamilton, S.R., Green, J., Jass, J., Watson, P., Lynch, H.T., Trent, J.M., Delachapelle, A., Kinzler, K.W., and Vogelstein, B.
(1993). Mutations of a mutS homolog in hereditary nonpolyposis colorectal cancer. Cell 75, 1215-1225.

Levinson, G., and Gutman, G.A. (1987a). High frequencies of short frameshifts in poly-CA/TG tandem repeats borne by bacteriophage M13 in Escherichia coli K-12. Nucleic Acids Res 15, 5323-5338.

Levinson, G., and Gutman, G.A. (1987b). Slipped-strand mispairing: A major mechanism for DNA sequence evolution. Mol Biol Evol 4, 203-221.

Li, G.M., and Modrich, P. (1995). Restoration of mismatch repair to nuclear extracts of H6 colorectal tumor cells by a heterodimer of human MutL homologs. Proc Natl Acad Sci USA 92, 1950-1954.

Longley, M.J., Pierce, A.J., and Modrich, P. (1997). DNA polymerase delta is required for human mismatch repair in vitro. J Biol Chem 272, 10917-10921.

Lu, A.L., Clark, S., and Modrich, P. (1983). Methyl-directed repair of DNA base-pair mismatches in vitro. Proc Natl Acad Sci USA 80, 4639-4643.

Marinus, M.G. (1976). Adenine methylation of Okazaki fragments in Escherichia coli. J Bacteriol 128, 853-854.

Modrich, P., Anraku, Y., and Lehman, I.R. (1973). Deoxyribonucleic acid ligase. Isolation and physical characterization of the homogeneous enzyme from Escherichia coli. J Biol Chem 248, 7495-7501.

Modrich, P., and Lehman, I.R. (1970). Enzymatic joining of polynucleotides. IX. A simple and rapid assay of polynucleotide joining (ligase) activity by measurement of circle formation from linear deoxyadenylate-deoxythymidylate copolymer. J Biol Chem 245, 3626-3631.

Modrich, P., and Lehman, I.R. (1971). Enzymatic characterization of a mutant of Escherichia coli with an altered DNA ligase. Proc Natl Acad Sci USA 68, 1002-1005.

Modrich, P., Lehman, I.R., and Wang, J.C. (1972). Enzymatic joining of polynucleotides. XI. Reversal of Escherichia coli deoxyribonucleic acid ligase reaction. J Biol Chem 247, 6370-6372.

Modrich, P., and Richardson, C.C. (1975a). Bacteriophage T7 Deoxyribonucleic acid replication in vitro. A protein of Escherichia coli required for bacteriophage T7 DNA polymerase activity. J Biol Chem 250, 5508-5514.

Modrich, P., and Richardson, C.C. (1975b). Bacteriophage T7 deoxyribonucleic acid replication in vitro. Bacteriophage T7 DNA polymerase: an an emzyme composed of phage- and host-specific subunits. J Biol Chem 250, 5515-5522.

Nicolaides, N.C., Papadopoulos, N., Liu, B., Wei, Y.-F., Carter, K.C., Ruben, S.M., Rosen, C.A., Haseltine, W.A., Fleischmann, R.D., Fraser, C.M., Adams M.D., Venter, J.C., Dunlop, M.G., Hamilton, S.R., Petersen, G.M., Delachapelle, A., Vogelstein, B. and Kinzler, K.W. (1994). Mutations of two PMS homologues in hereditary nonpolyposis colon cancer. Nature 371, 75-80.

Papadopoulos, N., Nicolaides, N.C., Wei, Y.F., Ruben, S.M., Carter, K.C., Rosen, C.A., Haseltine, W.A., Fleischmann, R.D., Fraser, C.M., Adams, M.D., Venter, J.C., Hamilton, S.R., Petersen, G.M., Watson, P., Lynch, H.T., Peltomaki, P., Mecklin, J.P., Delachapelle, A., Kinzler, K.W. and Vogelsstein, B. (1994). Mutation of a mutL homolog in hereditary colon cancer. Science 263, 1625-1629.

Parsons, R., Li, G.M., Longley, M.J., Fang, W.H., Papadopoulos, N., Jen, J., de la Chapelle, A., Kinzler, K.W., Vogelstein, B., and Modrich, P. (1993). Hypermutability and mismatch repair deficiency in RER+ tumor cells. Cell 75, 1227-1236.

Pukkila, P.J., Peterson, J., Herman, G., Modrich, P., and Meselson, M. (1983). Effects of high levels of DNA adenine methylation on methyl-directed mismatch repair in Escherichia coli. Genetics 104, 571-582.

Su, S.S., and Modrich, P. (1986). Escherichia coli mutS-encoded protein binds to mismatched DNA base pairs. Proc Natl Acad Sci USA 83, 5057-5061.

Thibodeau, S.N., Bren, G., and Schaid, D. (1993). Microsatellite instability 
in cancer of the proximal colon. Science 260, 816-819.

Wagner, R., Jr., and Meselson, M. (1976). Repair tracts in mismatched DNA heteroduplexes. Proc Natl Acad Sci USA 73, 4135-4139.

Welsh, K.M., Lu, A.L., Clark, S., and Modrich, P. (1987). Isolation and characterization of the Escherichia coli mutH gene product. J Biol Chem 262, 15624-15629.
Worth, L., Jr., Clark, S., Radman, M., and Modrich, P. (1994). Mismatch repair proteins MutS and MutL inhibit RecA-catalyzed strand transfer between diverged DNAs. Proc Natl Acad Sci USA 91, 3238-3241.

Yamaguchi, M., Dao, V., and Modrich, P. (1998). MutS and MutL activate DNA helicase II in a mismatch-dependent manner. J Biol Chem 273, 9197-9201.

Open Access This article is distributed under the terms of the Creative Commons Attribution License which permits any use, distribution, and reproduction in any medium, provided the original author(s) and source are credited. 